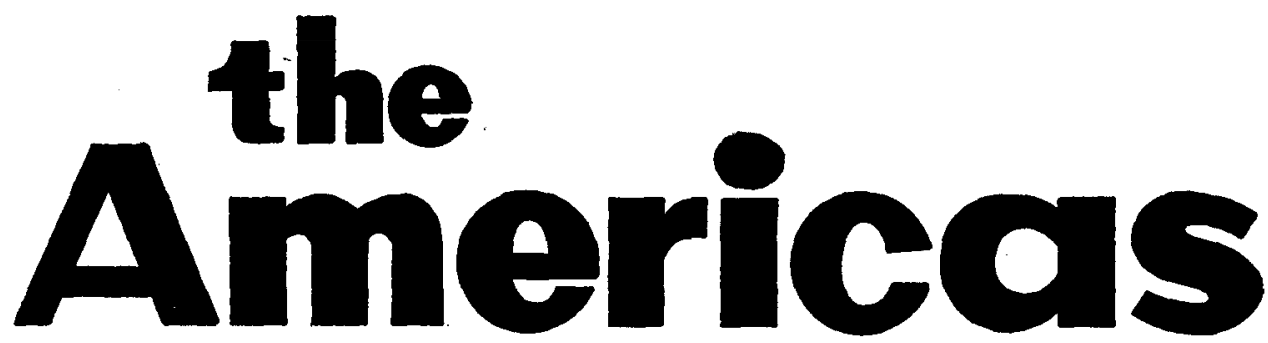

A QUARTERLY REVIEW OF INTER-AMERICAN CULTURAL HISTORY

The Franciscan Doctrinero versus the Franciscan Misionero in Seventeenth-Century Peru........Antonine Tibesar

An Analysis of the Missionary Methods of the Puritans Juan A. Ortega y Medina

Periodicals for Women in Mexico During the Nineteenth Century........................Jane Herrick

Apropos an Article on Gabriela Mistral.... Margaret Bates 145

The War With the United States and the Crisis in Mexican Thought............................ Hale 153

Sixteenth-Century Reading in the Indies. .José Torre Revello 175 DOCUMENTS $\ldots \ldots \ldots \ldots \ldots \ldots \ldots \ldots \ldots \ldots \ldots \ldots \ldots$

INTER-AMERICAN NOTES $\ldots \ldots \ldots \ldots \ldots \ldots \ldots \ldots \ldots, 191$

BOOK REVIEWS .......................... 196

(Listed on inside front cover)

Copyright, 1957

\title{
ACADEMY OF AMERICAN FRANCISCAN HISTORY
}

The contents of THE AMERICAS are indexed in the Catbolic Periodical Index and the International Index to Periodicals, and abstracted in Historical Abstracts.

In citing, use $T A m$ 


\section{EDITORIAL STAFF}

Mathias C. Kiemen, O.F.M. Managing Editor
Bede A. Dauphinee, O.F.M. Assistant Managing Editor

JANe HerRick

Assistant Editor

Francis B. Steck, O.F.M.

Quincy College

Maynard Geiger, O.F. M.

Santa Barbara, California

Lázaro Lamadrid, O. F. M. Washington, D.C.
Fidel Chauvet, O.F.M.

Mexico City, D.F.

Lino G. Canedo, O.F. M. Washington, D.C.

Michael B. McCloskey, O.F.M. Siena College

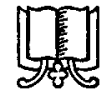

\section{ADVISORY EDITORS}

Silvio Zavala

Pan American Institute

of Geography and History

George P. Hammond

University of Californiz

Carlos E. Castañeda

University of Texas

John Tate Lanning

Duke University

Roscoe R. HiLl

National Archives (retired)

Henry Gratran Doyle George Washington University

Javier Malagón-Barceló Pan American Union

Charles C. Cumberland Michigan State University

Robert C. SMith University of Pennsylvania

Stanley R. Ross

University of Nebraska
John P. Harrison

Rockefeller Foundation

Robert S. Chamberlain

Carnegie Institution of Washington

Ruth Lapham Butler

Newberry Library, Chicago

J. Manuel Espinosa

Department of State, Washington, D.C.

Manoel Cardozo

Catholic University of America

Donald C. Cutter

University of Southern California

Charles J. Bishro

University of Virginia

Philip Wayne Powell

University of California at Santa Barbara

A. L. BURT

University of Minnesota

Ernest J. Burrus, S.J. Institutum Historicum S.J., Rome

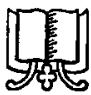

THE AMERICAS is published in July, October, January, and April; annual subscription United States and Canada $\$ 6.00$; all other countries $\$ 4.00$. Address all communications to the Managing Editor, $5401 \mathrm{~W}$. Cedar Lane, Washington 14, D. C. Opinions expressed are the responsibility of contributors.

Second-class mail privileges autborized at Washington, D.C., and Baltimore, Maryland. 